\title{
Spatial distribution by Canistropsis microps (E. Morren ex Mez) Leme (Bromeliaceae: Bromelioideae) in the Atlantic rain forest in Ilha Grande, Southeastern Brazil
}

\author{
Nunes-Freitas, $A F^{\mathrm{a} *}$ and Rocha, CFD. ${ }^{\mathrm{b}}$ \\ aDepartamento de Ciências Ambientais, Instituto de Florestas, Universidade Federal Rural do Rio de Janeiro - UFRRJ, \\ Rodovia BR-465, Km 7, CEP 23890-000, Seropédica, RJ, Brazil \\ bDepartamento de Ecologia, Instituto de Biologia Roberto Alcântara Gomes - IBRAG, \\ Universidade do Estado do Rio de Janeiro - UERJ, \\ Rua São Francisco Xavier, 524, CEP 20550-011, Rio de Janeiro, RJ, Brazil \\ *e-mail: afnfreitas@ufrrj.br \\ Received September 28, 2005 - Accepted February 1, 2006 - Distributed August 31, 2007
}

(With 4 figures)

\begin{abstract}
Canistropsis microps (Bromeliaceae: Bromelioideae) is an endemic species of Atlantic rain forest areas in Rio de Janeiro State, which are very abundant in not very disturbed forests in Ilha Grande, on the southern coast of the State. In this study, we analyzed the vertical and horizontal distribution patterns of the species in an area of rain forest with little evidence of disturbance at Vila Dois Rios, Ilha Grande, relating the patterns to sunlight in the microhabitat. We also identified the types of substrate used by the species and the rate of asexual reproduction. Canistropsis microps had high densities (estimated at 84,425 rosettes/ha), and has an aggregated distribution $\left(I_{d}=2.86\right)$. About $80 \%$ of the rosettes were generated by clonal growth, whereas less than $20 \%$ were produced from seedlings. Most of the rosettes were found on straight tree trunks $(\mathrm{DBH}>50 \mathrm{~cm})$. There was a significant inverse correlation between the incidence of sunlight in the habitat and the abundance of individuals. Rosettes were found up to a maximum height of $9.5 \mathrm{~m}$, but most occured between 1.5 and $5.5 \mathrm{~m}$, where light varied from 25 to $50 \mu \mathrm{mol} . \mathrm{s}^{-1} . \mathrm{m}^{-2}$. We conclude that vertical and horizontal distribution patterns in $C$. microps may be partially explained by the occurrence of appropriate substrate, an intensity of sunlight favorable to the development of the species and to a high rate of vegetative reproduction.
\end{abstract}

Keywords: Canistropsis microps, Bromeliaceae, spatial distribution, substrate, Atlantic Rainforest.

\section{Distribuição espacial de Canistropsis microps (E. Morren ex Mez) Leme (Bromeliaceae: Bromelioideae) na Mata Atlântica da Ilha Grande, Sudeste do Brasil}

\section{Resumo}

Canistropsis microps (Bromeliaceae: Bromelioideae) é uma espécie endêmica das áreas de Mata Atlântica do Estado do Rio de Janeiro, sendo muito abundantes em florestas pouco perturbadas da Ilha Grande, na costa sudeste do Estado. Nesse estudo, nós analisamos o padrão de distribuição vertical e horizontal da espécie em uma área de floresta com pouca evidência de distúrbio na Vila Dois Rios, Ilha Grande, relacionando os padrões à incidência de luz no microhabitat. Nós também identificamos os tipos de substratos usados pela espécie e a taxa de reprodução assexuada. Canistropsis microps possui elevadas densidades (estimada em 84.425 rosetas/ha), e uma distribuição agregada (Id = 2,86). Cerca de $80 \%$ das rosetas são geradas pelo crescimento clonal, enquanto menos que $20 \%$ são produzidos a partir de sementes. Muitas das rosetas foram encontradas em troncos retos de árvores (DAP $>50 \mathrm{~cm}$ ). Houve uma correlação significativa inversa entre a incidência da luz solar no habitat e abundância de de indivíduos. As rosetas foram encontradas até uma altura máxima de $9,5 \mathrm{~m}$, mas a maioria ocorreu entre 1,5 e $5,5 \mathrm{~m}$, onde a luz variou de $25 \mathrm{a} 50 \mu \mathrm{mol} \cdot \mathrm{s}^{-1} \cdot \mathrm{m}^{-2}$. Nós concluímos que o padrão de distribuição vertical e horizontal em C. microps pode ser parcialmente explicada pela ocorrência de um substrato apropriado, uma intensidade de luz solar favorável para o desenvolvimento da espécie e a alta taxa de reprodução vegetativa.

Palavras-chave: Canistropsis microps, Bromeliaceae, distribuição espacial, substrato, Mata Atlântica.

\section{Introduction}

The success of a plant species in the colonization of a habitat and in the occupation of a substratum type, resulting in the configuration of a certain pattern of space distribution, can be explained by the interaction of a group of factors, both intrinsic and extrinsic to the species. Among the intrinsic factors, the type of reproduction, the capacity and form of dispersion (Silvertown, 1987), the metabolic capacities of the species (Martin, 1994) and the life form (Benzing, 1980) can be mentioned. Among the extrinsic factors are the readiness of germination and development 
sites (Silvertown, 1987), different environmental factors (light, humidity and temperature) (Pittendrigh, 1948; Johanson, 1974; Sugden \& Robins, 1979; Ackerman, 1986; Fischer and Araújo, 1995; Medina, 1996; Rossi et al., 1997; Almeida et al., 1998) and the interactions with pollinators and with dispersers. The combined action of extrinsic and intrinsic factors, or the interaction among some of them, determines the success of the establishment of a given plant species.

The family Bromeliaceae can be described ecologically as a group of stress-resistant tropical herbs that occur in the most varied habitats, containing terrestrial, epiphytic and saxicolous species (Benzing, 1980), as well as different morpho-physiologic types (Smith et al., 1986). Among the 83 families of vascular plants that include epiphytes, the family Bromeliaceae is the second largest in number of species (Gentry and Dodson, 1987). The morpho-physiologic differences among the bromeliad species can have a diversified distribution in the vertical stratum of the forest (Pittendrigh, 1948; Aragão, 1967) in response to existing gradients of light and humidity (Benzing, 1980, 1990). On the other hand, the capacity to emit great amounts of sprouts by clonal growth (Benzing, 1980; Barracho, 1997) is responsible for high local densities of rosettes in certain species (Barracho, 1997), which gives them greater efficiency to obtain the resources available in the environment (Birch and Hutchings, 1994).

Canistropsis microps (E. Morren ex Mez) Leme is an endemic species from Rio de Janeiro state, southeastern Brazil, occurring in high abundance in the Atlantic forest of Ilha Grande in the southwestern coast of the state. It is characterized as a shade tolerant species consisting of the epiphytic community of the inferior stratum of the forest (Almeida et al., 1998; Leme, 1998). Leme (1998) argues that clonal growth is an outstanding characteristic of the species. It has been suggested that this species occupies several substrata, it is preferentially epiphytic and it is distributed vertically on the arbustive-arboreal stratum (Almeida et al., 1998).

In this study, we investigated the spatial distribution of Canistropsis microps, vertically and horizontally, relating its frequency of occurrence with light in the forest habitat. Additionally, we evaluated whether C. microps occupies the available substrata at the same frequency in which they occur in the forest or if there is a preference of substrata used by the species.

\section{Material and Methods}

Study Area - The study was carried out in December, 1996 and January, 1997 in an Atlantic forest area close to the Vila Dois Rios in Ilha Grande (23 $11^{\prime} \mathrm{S}$ and $\left.44^{\circ} 12^{\prime} \mathrm{W}\right)$ in the municipality of Angra dos Reis, Rio de Janeiro state, Brazil. Ilha Grande has a warm and wet climate with a mean monthly temperature of $23^{\circ} \mathrm{C}$ and an annual rainfall of approximately 2,300 mm (Araújo and Oliveira, 1988). The island has a plant cover typical of the Atlantic forest with different levels of regenera- tion. The study was carried out in a forest area with little evidence of disturbance located on the oceanic side of the island at $240 \mathrm{~m}$ high. The height of the canopy varies from 25 to 30 meters having an abundance of large trees, a sparse understory, a deep leaf-litter layer $(5-20 \mathrm{~cm})$ and a rich and abundant epiphytic flora.

In order to evaluate the types of used substrate and the form of occupation of the space, we demarcated 100 parcels of $4 \mathrm{~m}^{2}(2 \times 2 \mathrm{~m})$ in the forest. The plots were established on 10 lines at intervals of $20 \mathrm{~m}$ long and between the lines. In each plot we estimated (up to a maximum height of $10 \mathrm{~m}$ ): the total number of rosettes of $C$. microps and the number of rosettes per substratum type (ground, liana, rock, tree trunk, branch, log, bush, and root). The frequency of occurrence for each of the potential substrates was estimated by registering its occurrence inside the plots and the tree trunks were divided into two size classes: $\mathrm{BHD}<50 \mathrm{~cm}$ and $\mathrm{BHD}>50 \mathrm{~cm}$.

We considered the ramet originating from clonal growth (sensu Eriksson, 1993) or an isolated adult individual originating from a seed as a "rosette" or individual and the grouping of rosettes formed by clonal growth as a "genet". We calculated the frequencies of occupation (in \%) by the bromeliads on each substratum type in order to evaluate whether there is a preferential substratum. We also calculated the frequencies of occurrence (in \%) of each of the potentially available substrates. To test if C. microps occupies substrates at the same ratio at which they are available in the forest or if they are using these in proportions that differ from their availability, we used the Kolmogorov-Smirnov test (Zar, 1999).

To analyze the spatial distribution pattern (random, aggregated, or regular) of the ramets and genets in the forest, we used the Morisita's Index of Dispersion (Id):

$$
\mathrm{I}_{\mathrm{d}}=\mathrm{n} \frac{\Sigma \mathrm{x}_{\mathrm{i}}^{2}-\Sigma \mathrm{x}_{\mathrm{i}}}{\left(\Sigma \mathrm{x}_{\mathrm{i}}\right)^{2}-\Sigma \mathrm{x}_{\mathrm{i}}}
$$

where $n$ is the number of sampled parcels and $x_{i}$ is the number of ramets or genets in each sampled parcel (Brower et al., 1997). The significance of the index of dispersion of Morisita was tested by the F-test for significance of Id ( $\mathrm{gl}=\mathrm{n}-1 ; \mathrm{p}<0.05)$ (Poole, 1974):

$$
\mathrm{F}=\frac{\mathrm{I}_{\mathrm{d}}(\mathrm{N}-1)+\mathrm{n}-\mathrm{N}}{\mathrm{n}-1}
$$

where Id is the calculated value of the index of dispersion of Morisita, $\mathrm{n}$ is the number of parcels, $\mathrm{N}$ is the total number of individuals found in all of the $n$ parcels.

Later, to estimate a rate of the occurrence of assexual reproduction in $C$. microps, we randomly picked 30 parcels $(2 \times 2 \mathrm{~m})$ in the same area where we estimated up to a height of $10 \mathrm{~m}$ the number of groupings, the number of rosettes per grouping, the number of isolated rosettes and the number of rosettes of a small size (10 to $30 \mathrm{~mm}$ of diameter) supposedly originating from seeds.

To evaluate the effect of the variation on the light in the microhabitats in the distribution pattern of $C$. microps, we used the same 100 parcels of $4 \mathrm{~m}^{2}$ demarcated for the density measures. In each plot, we took five measures of 
light (in the vertexes and at the center of each parcel) using a luximeter (accuracy of $1 \mathrm{lux}$ ) at a height of $1.5 \mathrm{~m}$. We took all measures of light on the same day with good weather conditions between 11:00 and 13:00 hours in order to minimize the effects of the differences in light due to the inclination of the solar rays on different days, in the different conditions of time and at different times. To evaluate to what extension the light affects the distribution of $C$. microps in the study area, we related the abundance (log-transformed) of $C$. microps individuals inside each parcel with the mean intensity, the maximum intensity and the minimum intensity of light (all log-transformed) of the respective parcel using regression analyses (Zar, 1999). The data of light obtained in lux were later transformed to $\mu \mathrm{mol} . \mathrm{s}^{-1} \cdot \mathrm{m}^{-2}$ according to Li-Cor (1994).

To relate the vertical variation in the abundance of C. microps to the vertical gradient of light incidence in the forest, we estimated the vertical distribution of C. microps along a gradient of heights. In this analysis, we used 25 trees with straight trunks and, with the aid of a $10 \mathrm{~m}$ long pole, demarcated vertical intervals of $0.5 \mathrm{~m}$ and estimated the number of rosettes occurring in each of these intervals. Furthermore, we measured the light at each $0.5 \mathrm{~m}$ interval of height with a luximeter in ten of the 25 trees. The light was measured as mentioned above. The variations in the frequencies of occupation of the vertical strata for the plants were tested to evaluate if they adjusted to a normal distribution. We tested possible differences in the mean values of light incidence in the height intervals by an Analysis of Variance (ANOVA) and we used a regression analysis between light and height (Zar, 1999). We used the total number of bromeliads found in each vertical interval of height as the measure representing the total abundance of individuals in the vertical stratum. The variation in the mean abundance along the vertical gradient was used as a measure of the vertical distribution of the species in the substratum. These values were related to the mean intensity, the maximum intensity and the minimum intensity of light in each of the respective height intervals in the forest using a quadratic analysis of regression (Zar, 1999).

\section{Results}

We found a total of 3,377 rosettes and 58 groupings of $C$. microps in the sampled area, resulting in an estimated density of 84,425 rosettes/ha and of 4,833 groupings/ha. In terms of substrates used by the plant, the highest percentage of the rosettes was found occupying the straight trunks of trees with BHD $>50 \mathrm{~cm}(61 \%)$ (Figure 1). The distribution of frequencies of rosettes of $C$. microps on the substrates used differed statistically from the distribution of available substrates in the parcels (Kolmogorov-Smirnov, Dmax $=0.3498 ; \mathrm{P}<0.01)$. The calculated value of the Morisita's index of dispersion (Id) was 2.86 ( $F=64.4$ and $\left.I_{d} \neq 1 ; p<0.001\right)$ for the distribution of rosettes, whereas for the distribution of groupings it was 2.77

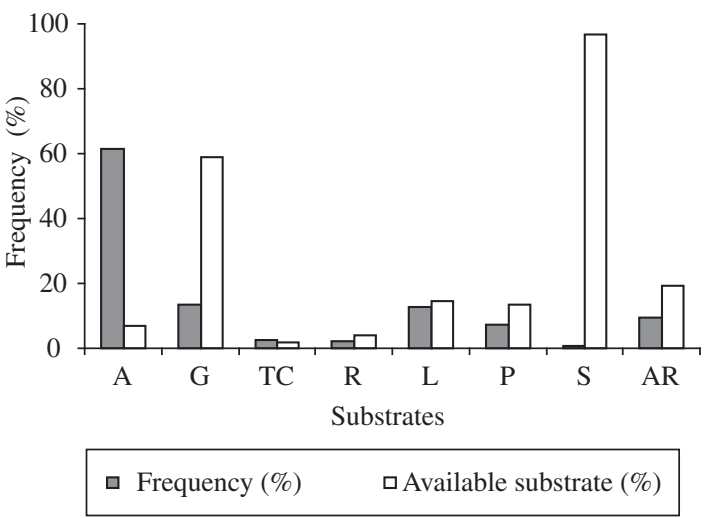

Figure 1. Adult individual frequency of Canistropsis microps ocupying each kind of substrate in the primary Forest of Ilha Grande and the respective availability frequency of each kind of substrate available. $\mathrm{A}=$ tree trunk with BHD $>50 \mathrm{~cm} ; \mathrm{G}=$ branch; $\mathrm{TC}=$ fallen trunk; $\mathrm{R}=$ root; $\mathrm{L}=$ liana; $\mathrm{P}=$ rocks; $\mathrm{S}=$ soil $; \mathrm{AR}=$ trees and bushes with $\mathrm{BHD}<50 \mathrm{~cm}$. (Kolmogorov-Smirnov Test, $\mathrm{D}_{\max }=0.3498$; $\mathrm{P}<0.01)$.

$\left(F=4.5\right.$ and $\left.I_{d} \neq 1 ; p<0.001\right)$ indicating that the species has an aggregated distribution pattern.

Considering the estimated number of rosettes, $827(80.4 \%)$ originated from clonal growth and $201(19.6 \%)$ were of a small size. We did not find any C. microps rosettes growing isolated in any of the 30 sampled parcels. The mean number of rosettes per grouping was $27.6+39.6$ ( $\mathrm{N}=58$ groupings). The mean number of groupings was $1.9+2.3$ per parcel $\left(\mathrm{N}_{\text {adults }}=827\right.$ individuals; $\mathrm{N}_{\text {youngs }}=201$ individuals). The mean number of isolated young individuals was $6.7+9.5$ per parcel $(\mathrm{N}=30$ parcels $)$.

In the present study, $C$. microps rosettes were found only in a mean maximum height of $9.5 \mathrm{~m}( \pm 0.2)$ above ground (Figure 2). Along this strip of heights, the abundance of $C$. microps rosettes on straight-trunk trees varied significantly among the 19 vertical classes of $0.5 \mathrm{~m}$ height (Figure 2). There was no significant difference in the mean intensity of light in the different classes of height of the vertical stratum of the forest (ANOVA: $\left.\mathrm{F}=0.884 ; \mathrm{R}^{2}=0.096 ; \mathrm{P}=0.603 ; \mathrm{n}=178\right)$. Nevertheless, the data indicated a successive decrease of the mean light from $10 \mathrm{~m}$ to ground level in the respective 19 height classes considered (Figure 2) and there was a significant relationship between the light and height $(\mathrm{F}=20.152$; $\left.\mathrm{R}^{2}=0.13 ; \mathrm{P}<0.001 ; \mathrm{n}=178\right)$. The highest densities of adult $C$. microps rosettes occurred at heights between 1.5 and $5.5 \mathrm{~m}$ above the ground. The vertical variation in the abundance of rosettes of $C$. microps followed a normal distribution $\left(\chi^{2}=7.200 ; \mathrm{P}>0.05\right)$ (Figures 2 and 3 ). There was a significant and negative relationship between the minimum intensity of light in the height classes and the respective abundance of $C$. microps rosettes in the same classes $\left(\mathrm{F}=7.246 ; \mathrm{R}^{2}=0.326 ; \mathrm{P}=0.017 ; \mathrm{n}=17\right.$; $\mathrm{y}=5.314-1.480 \mathrm{x}$ ) (Figure 3 ). There was no significant 

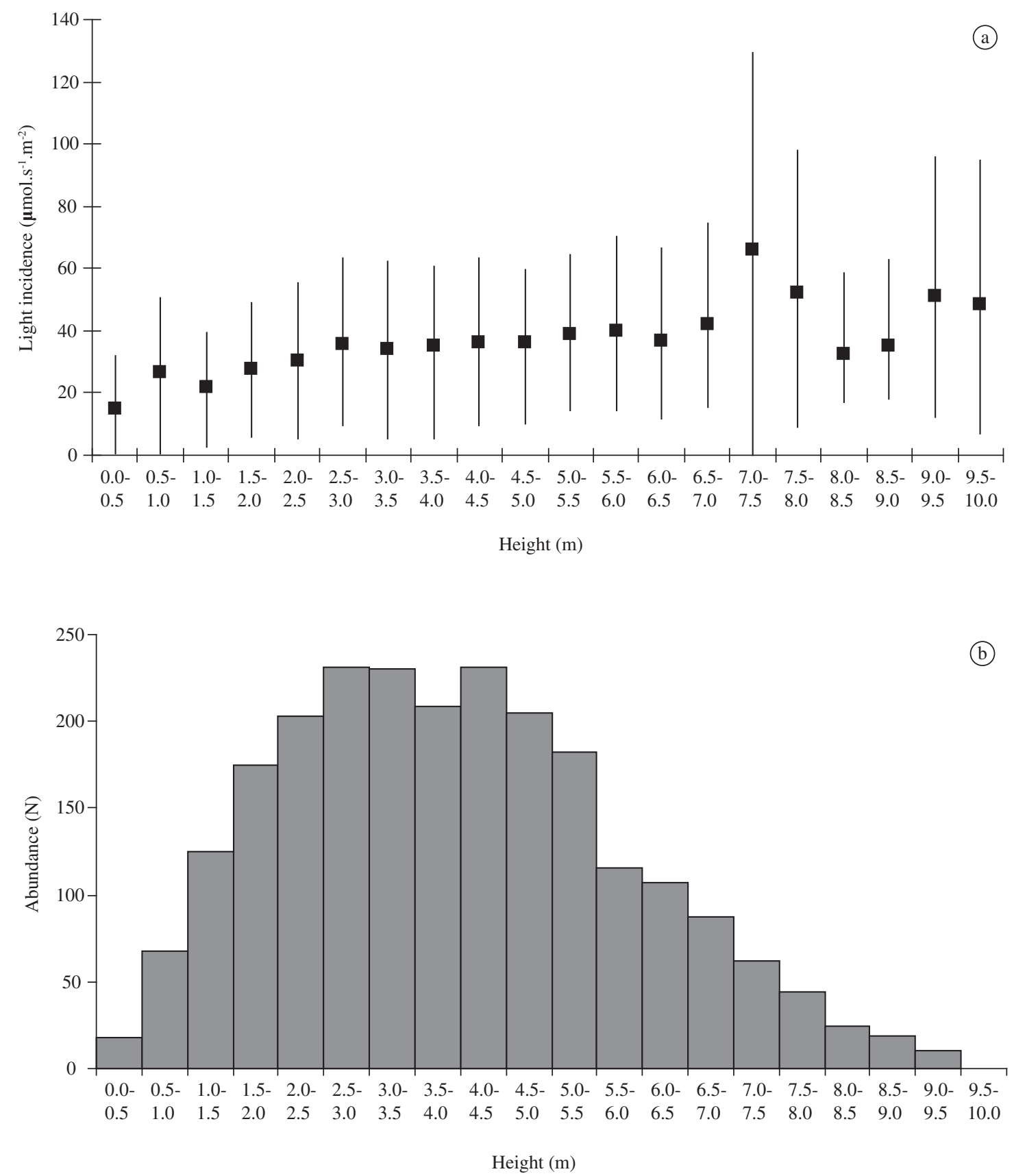

Figure 2. Medium light variation (in $\mu \mathrm{mol} . \mathrm{s}^{-1} \cdot \mathrm{m}^{-2}$ ) in different groups of height (a) in tree trunks from a soil level up to $10 \mathrm{~m}$ (height $0.5 \mathrm{~m}$ above maximum where the plant is found in the forest) and number of individuals of Canistropsis microps (b) in the same groups of height (b). In graph (a), the lines represent \pm 1 standard deviation. $\mathrm{N}_{\text {rosetes }}=2346$.

relationship between the mean light and abundance of C. microps $\left(\mathrm{F}=0.740 ; \mathrm{R}^{2}=0.042 ; \mathrm{P}=0.402 ; \mathrm{n}=19\right)$, nor between the maximum light and abundance of $C$. microps $\left(\mathrm{F}=0.403 ; \mathrm{R}^{2}=0.023 ; \mathrm{P}=0.534 ; \mathrm{n}=19\right)$.

The relationship between the mean intensity of light in the parcels and the respective abundance of $C$. microps rosettes in the same parcels was inverse and significant $\left(\mathrm{F}=7.029 ; \mathrm{R}^{2}=0.091 ; \mathrm{P}=0.010 ; \mathrm{n}=72\right.$; $\mathrm{y}=4.162-0.271 \mathrm{x}$ ) (Figure 4), as was the relationship between the maximum intensity of light in the parcels and the respective abundance of $C$. microps $(\mathrm{F}=8.056$; $\left.\mathrm{R}^{2}=0.103 ; \mathrm{P}=0.006 ; \mathrm{n}=72 ; \mathrm{y}=4.358-0.263 \mathrm{x}\right)$ (Figure 4). There was no significant relationship between the minimum intensity of light and abundance of C. microps in the parcels $\left(\mathrm{F}=1.410 ; \mathrm{R}^{2}=0.020\right.$; $\mathrm{P}=0.239 ; \mathrm{n}=72$ ). 


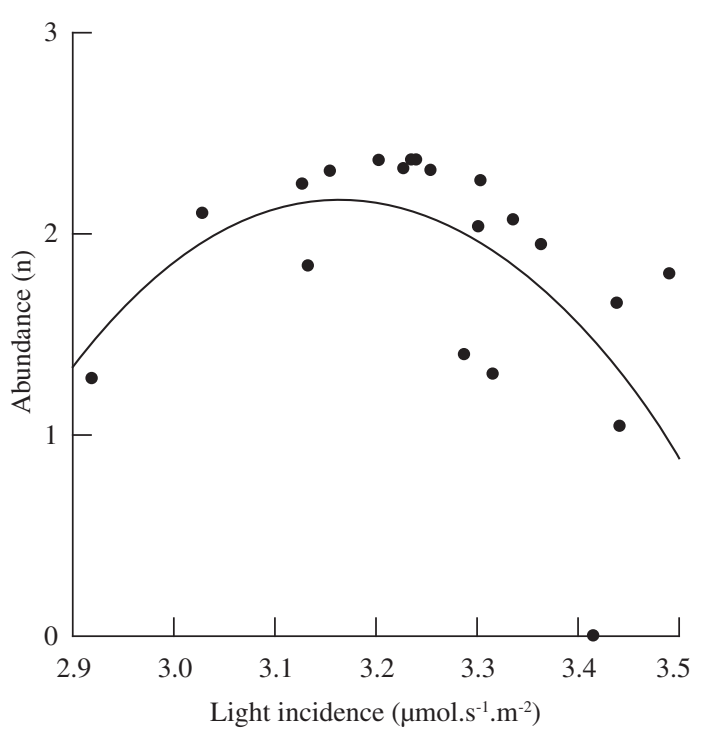

Figure 3. Relationship between minimum light incidence logarithm in groups of height (in $\mu \mathrm{mol} . \mathrm{s}^{-1} . \mathrm{m}^{-2}$ ) and the individual abundance logarithm of Canistropsis microps in the primary forest of Ilha Grande $\left(\mathrm{F}=7.246 ; \mathrm{R}^{2}=0.326\right.$; $\mathrm{P}=0.017 ; \mathrm{n}=17)$. The straight line is described according to the equation $\mathrm{y}=5.314-1.480 \mathrm{x}$.

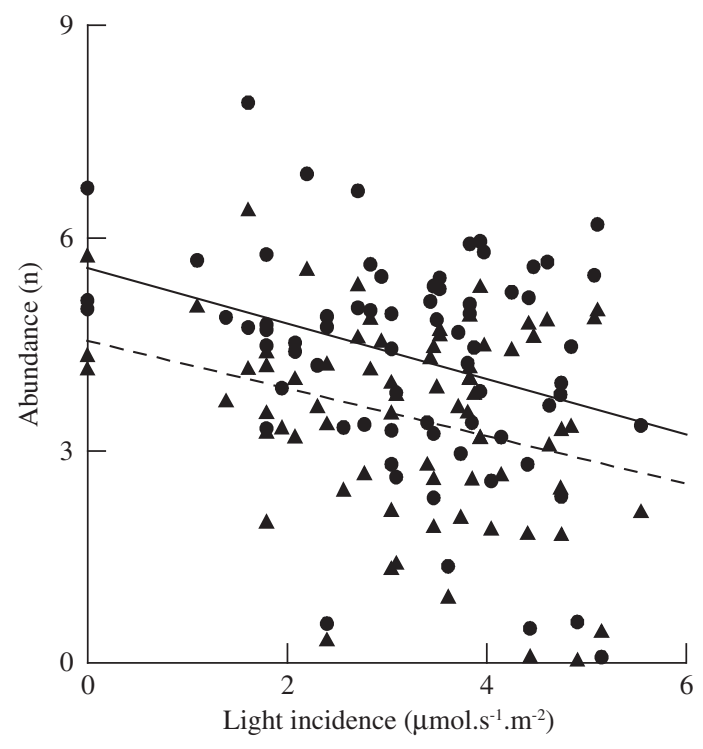

Figure 4. Relationship between medium light incidence logarithm (dots) and the maximum luminosity (triangles) in the parcels (in $\mu \mathrm{mol} . \mathrm{s}^{-1} . \mathrm{m}^{-2}$ ) and the individual's abundance logarithm of Canistropsis microps in the primary forest of Ilha Grande. The uninterrupted line describes the straight line of the relationship between medium intensity and abundance $\left(\mathrm{F}=7.029 ; \mathrm{R}^{2}=0.091 ; \mathrm{P}=0.010 ; \mathrm{n}=72\right.$ ) and is described by the equation $\mathrm{y}=4.162-0.271 \mathrm{x}$, while the dotted line describes the straight line of the relationship between the maximum intensity and abundance $(\mathrm{F}=8.056$; $\left.\mathrm{R}^{2}=0.103 ; \mathrm{P}=0.006 ; \mathrm{n}=72\right)$ and is described by the equation $\mathrm{y}=4.358-0.263 \mathrm{x}$.

\section{Discussion}

The data indicated that there is a high population density of Canistropsis microps in the area studied. In a study comparing the populations of different bromeliad species in the same area, Almeida et al. (1998) found that C. microps was the bromeliad species with the highest density, which is corroborated by our data. Moreover, our data demonstrate that this species presents an aggregated pattern of distribution, which can be explained by some factors such as the high rates of assexual reproduction (clonal growth), the demand for occupation of a certain substratum, and favorable lighting intensity for this shade tolerant bromeliad species in the inferior stratum of the forest.

In the Atlantic forest of Ilha Grande, C. microps has a high rate of clonal growth, which is considered common among herbaceous and arbustive plants, and it is an evolutionarily old reproductive strategy that is widespread among different taxa (Silvertown, 1987) and quite common among the Bromeliaceae (Barracho, 1997). This type of reproduction can result in an aggregated distribution pattern, as it promotes the concentration of individuals on a given substratum (Henriques et al., 1984; Crawley \& Rossi, 1990), and depends on the degree of disturbance of the area and of the available space (Crawley \& Rossi, 1990). Plants with this growth mechanism can distribute many ramets to obtain light, nutrition and water in a habitat, substantially benefitting resource patches in the environment (Alpert, 1991; Birch and Hutchings, 1994; Stueffer et al., 1994; Evans and Cain, 1995), specially in heterogeneous ones (Evans and Cain, 1995) or if resources are locally scarce and need to be monopolized (De Kroon and Schieving, 1990). Furthermore, to begin and to complete the flowering and fructification processes successfully, a considerable accumulation of energy resources needs to be gathered (Harper, 1977; Costa et al., 1988).

Canistropsis microps is a type of bromeliad capable of occupying different substrata in the forest (Almeida et al., 1998) and can be classified as a species with facultative habits (Fischer and Araújo, 1995). Plants that have facultative habits can fixate in different substrate types within a community (Benzing, 1990; Freitas et al., 1998). However, when we did more refined quantitative analyses detailing the frequencies of use of each substratum type, we observed that these bromeliad attach to different kinds of substratum, but mostly to tree trunks and branches. In the case of C. microps, the preferential occupation of tree trunks suggests that this substratum creates conditions favoring a better use of available resources and provides more favorable environmental conditions, such as humidity, temperature and, mainly, light. In general, it is mentioned that various factors can influence preferences in certain fixation sites for epiphytes, such as the angle of the branches, accumulation of organic matter on larger or smaller scales between branches (Ingram and Nadkarni, 1993), or the physical and chemical characteristics of tree bark (Oliver, 1930; Johansson, 1974; 
Schlesinger and Marks, 1977; Benzing, 1973, 1990; Dejean and Olmsted, 1997). Epiphytes that occupy the tree canopies find a very dynamic and heterogeneous environment (Zotz, 1997) with different types of substrata (Benzing, 1990; Kernan and Fowler, 1995; Zotz, 1997) due to the different microclimates imposed by the height and by the relative position of the plant (Parker, 1995). On the other hand, the epiphytes that need relatively low light (shade tolerant species) generally occupy the inferior strata of the forest (Pittendrigh, 1948; Laman, 1996), where the conditions of humidity and light are less stressful (Zotz, 1997), which appears to be the case of C. microps.

The data indicated that, in spite of the significant relationships, light has a relatively limiting effect on the vertical distribution and mainly on the horizontal distribution of $C$. microps. In terms of vertical distribution, the distribution of the plants can be explained only by the variation in the minimum intensity of light. The pattern of distribution of this species and the values of the light incidence in the vertical stratum show that most C. microps individuals vegetate at intermediate heights in the forest (between 1.5 and $5.5 \mathrm{~m}$ above ground), where the light intensity could be considered as providing better conditions for development in this species. However, other variables such as humidity and temperature could also explain an additional part of the vertical distribution of C. microps, as has been suggested for epiphytes in general (Benzing, 1980, 1990).

This characteristic suggests that $C$. microps needs intermediate intensities of light, such as the ones that occur in the lowest part of the forest, where the intensity of light is the most appropriate for its development. In the lower strata of the forest, the daily variation in light is lower (Aragão, 1967; Benzing, 1986), with a considerably reduced mean intensity. Many studies have shown that plants tend to occupy sites with light at which there will be a better physiological income, as it occurs, for instance, with some bromeliad species (Maxwell et al., 1995; Almeida et al., 1998; Scarano et al., 1999) and some Ficus species (Moraceae) (Laman, 1996). the vertical distribution of epiphytes was observed in much work (Schimper, 1903; Picado, 1913; Pittendrigh, 1948; Johansson, 1974; Bennett, 1986) and various studies indicate that this stratification is associated to the vertical variation of light (Pittendrigh, 1948; Johansson, 1974; Yoda, 1974; Bennett, 1987; Laman, 1996; Almeida et al., 1998).

The light explained a low portion of the horizontal variation of the bromeliads, which reinforces the idea that other factors besides light are responsible for explaining a complemental and substantial part of the distribution of $C$. microps. Other factors such as humidity, nutrients and, especially, the occurrence of a preferential substratum have been indicated as relevant to determine the occurrence and the distribution of epiphytic bromeliads (Benzing, 1980, 1990; Cogliatti-Carvalho and Rocha, 2001). As C. microps is a type of epiphyte that preferentially occupies trees trunks with BHD $>50 \mathrm{~cm}$, which are considered a more stable substratum for the epiphytes (Ackerman, 1986; Cogliatti-Carvalho and Rocha, 2001), this species can be found in a larger density in areas where trees with these characteristics are abundant.

The data suggest that, in the area of the Atlantic forest of the Ilha Grande, wherever there is little habitat disturbance and the presence of large trees, Canistropsis microps is likely to occur with a high density, as long as there is an appropriate degree of light. Subsequent studies that analyze the dispersion syndrome, the establishment rates and the development of individuals from seeds and that focus on the clonal growth of the species in more detail can help to understand other aspects involved in the distribution of $C$. microps. Additionally, the analysis of extrinsic factors such as temperature, humidity and nutrients should also be obtained to evaluate to what extent they affect the distribution of this species.

We conclude that the aggregated pattern, the predominant use of large trees for support and the patterns of vertical and horizontal distribution of Canistropsis microps in the Atlantic forest of Ilha Grande are partly the result of the interaction of intrinsic and extrinsic factors, including the occurrence of appropriate substrata of light intensity that is favorable to its development and of the high rate of vegetative reproduction in this species.

Acknowledgments - This study is part of the results of the Ecology, Conservation and management of ecosystems of Southeastern Brazil of the Department of Ecology of the Instituto de Biologia Roberto Alcântara Gomes from the Universidade do Estado do Rio de Janeiro and was supported by the Fundação de Amparo à Pesquisa do Estado do Rio de Janeiro - FAPERJ (Process No. E-26/170.884/2002). E. Leme kindly identified the bromeliad studied. We would also like to thank T.C. Rocha-Pessôa, M.B. Vecchi, A. Storni, R.D. Antonini, S.V. Matter and F.H. Hatano for help in the field. T.C. Rocha-Pessôa and D. Vrcibradic kindly reviewed the manuscript offering helpful suggestions. During the study, A. F. N. Freitas received a grant from the Coordenação de Aperfeiçoamento de Pessoal de Nível Superior - CAPES (Process No. 990207-7) and C. F. D. Rocha received grants from the Conselho Nacional do Desenvolvimento Científico e Tecnológico CNPq (Processes No 307653/2003-0 e 477981/2003-8).

\section{References}

ACKERMAN, JD., 1986. Coping with the epiphytic existence: pollination strategies. Selbyana, vol. 9, no. 1, p. 52-60.

ALMEIDA, DR., COGLIATTI-CARVALHO, L. and ROCHA, CFD., 1998. As bromeliáceas da Mata Atlântica da Ilha Grande, RJ: variação na composição e diversidade de espécies em três ambientes diferentes. Bromélia, vol. 5, no. 1-4, p. 54-65.

ALPERT, P., 1991. Nitrogen sharing among ramets increases clonal growth in Fragaria chiloensis. Ecology, vol. 72, no. 1, p. 69-80.

ARAGÃO, MB., 1967. Condições de hábitat e distribuição geográfica de algumas Bromeliaceae. Sellowia, vol. 19, p. 83-95. 
ARAÚJO, D. and OLIVEIRA, R., 1988. Reserva Biológica Estadual da Praia do Sul (Ilha Grande, Rio de Janeiro): lista preliminar da flora. Acta Botanica Brasilica, vol. I, no. 2, p. 83-94.

BARRACHO, GS., 1997. Propagação vegetativa em Bromeliaceae. Bromélia, vol. 4, no. 2, p. 23-27.

BENNETT, BC., 1986. Patchiness, diversity and abundance of relationships of vascular epiphytes. Selbyana, vol. 9, no. 1, p. $70-75$.

-, 1987. Spatial distribution of Catopsis and Guzmania (Bromeliaceae) in southern Florida. Bulletin of the Torrey Botanical Club, vol. 114, no. 3, p. 265-271.

BENZING, DH., 1973. The monocotyledons: their evolution and comparative biology. I. Mineral nutrition and related phenomena in Bromeliaceae and Orchidaceae. Quarterly Review of Biology, vol. 48, p. 277-290.

-, 1980, The Biology of the Bromeliads. Mad River Press, California, 305p.

-, 1986, Vegetative basis of vascular epiphytism. Selbyana, vol. 9 , no. 1, p. 23-43.

-, 1990, Vascular epiphytes. General biology and related biota. Cambridge Univ. Press, 354p.

BIRCH, CPD. and HUTCHINGS, MJ., 1994. Exploitation of patchily distributed soil resources by the clonal herb Glechoma hederaceae. Journal of Ecology, vol. 82, no. 3, p. 653-664.

BROWER, JE., ZAR, JH. and von ENDE, CN., 1997. Field \& Laboratory methods for general ecology. Wm. C. Brown Publishers, Winscosin, USA, 273p.

COGLIATTI-CARVALHO, L. and ROCHA, CFD., 2001. Spatial distribution and preferential substrate of Neoregelia johannis (Carriére) L.B. Smith (Bromeliaceae) in a disturbed area of Atlantic Rainforest at Ilha Grande, RJ, Brazil. Revista Brasileira de Botânica, vol. 24, no. 4, p. 389-394.

COSTA, CSB., SEELINGER, U. and CORDAZZO, CV., 1988. Distribution and phenology of Andropogon arenarius Hackel on coastal dunes of Rio Grande do Sul, Brazil. Revista Brasileira de Biologia, vol. 48, no. 3, p. 527-536.

CRAWLEY, MJ., 1990. The population dynamics of plants. Philosophical Transcriptis of the Royal Society of London B, vol. 330, no. 1257, p. 125-140.

DEKROON,H.andSCHIEVING,F., 1990. Resourcepartitioning in relation to clonal growth strategy, In GROENENDAEL, JM. and KROON, H. de, (eds.), Clonal growth in plants: regulation and function. The Hague, The Netherlands, SPB Academic Publishing, p. 113-130.

DEJEAN, A. and OLMSTED, I., 1997. Ecological studies on Aechmea bracteata (Swartz) Griseb. (Bromeliaceae). Journal of Natural History, vol. 31, no. 9, p. 1313-1334.

EVANS, JP. and CAIN, ML., 1995. A spatially explicit test of foraging behavior in a clonal plant. Ecology, vol. 76, no. 4 p. $1147-1155$.

ERIKSSON, O., 1993. Dynamics of genet in clonal plants. Trends in Ecology and Evolution, vol. 8, no. 9, p. 313-316.

FISCHER, EA. and ARAÚJO, AC., 1995. Spatial organization of a bromeliad community in the Atlantic rainforest, south-eastern Brazil. Journal of Tropical Ecology, vol. 11, no. 4, p. 559-567.
FREITAS, CA., SCARANO, FR. and WENDT, T., 1998. Habitat choice in two facultative epiphytes of the genus Nidularium (Bromeliaceae). Selbyana, vol. 19, no. 2, p. 236-239.

GENTRY, AH. and DODSON, CH., 1987. Diversity and biogeography of neotropical vascular epiphytes. Annals of the Missouri Botanical Garden, vol. 74, no. 2, p. 205-233.

HARPER, JL., 1977. Population biology in plants. Academic Press, London, 892p.

HENRIQUES, RPB., MEIRELLES, ML. and HAY, JD., 1984. Ordenação e distribuição de espécies de comunidades vegetais na praia de restinga de Barra de Maricá, Rio de Janeiro. Revista Brasileira de Botânica, vol. 7, no. 1, p. 27-36.

INGRAN, SW. and NADKARNI, NM., 1993. Composition and distribution of epiphytic organic matter in a Neotropical Cloud Forest, Costa Rica. Biotropica, vol. 25, no. 4, p. 370-383.

JOHANSON, D., 1974. Ecology of vascular epiphytes in west African rain forest. Acta Phytogeografica Sueccica, vol. 59, p. 1-136.

KERNAN, C. and FOWLER, N., 1995. Differential substrate use by epiphytes in Corcovado National Park, Costa Rica: a source of guild structure. Journal of Ecology, vol. 83, no. 1, p. 65-73.

LAMAN, TG., 1996. Specialization for canopy position by hemiepiphytic Ficus species in a Bornean rain forest. Journal of Tropical Ecology, vol. 12, no. 6, p. 789-803.

LEME, EMC., 1998. Canistropsis - Bromélias da Mata Atlântica. Salamandra Consultoria Editorial Ltda, Rio de Janeiro, Brasil, 143p.

LI-COR., 1994, Radiation Measurement Instruments. Li-Cor, Inc. Washington, USA, 24p.

MARTIN, CE., 1994. Physiological Ecology of the Bromeliaceae. The Botanical Review, vol. 60, no. 1, p. 1-82.

MAXWELL, C., GRIFFITHS, H., BORLAND, AM., YOUNG, AJ., BROADMEADOW, MSJ. and FORDHAM, MC., 1995. Short-term photosynthetic responses of the $\mathrm{C}_{3}$-CAM epiphyte Guzmania monostachia var. monostachia to tropical seasonal transitions under field conditions. Australian Journal of Plant Physiology, vol. 22, no. 5, p. 771-781.

MEDINA, E., 1996. CAM and $\mathrm{C}_{4}$ plants in the Humid Tropics, p. 56-88. In MULKEY, SS., CHAZDON, RL. and SMITH AP. (eds.). Tropical Forest Plant Ecophysiology, Chapman and Hall, ITP, New York.

OLIVER, WRB., 1930. New Zealand epiphytes. Journal of Ecology, vol. 18, no. 1, p. 1-50.

PARKER, GG., 1995. Structure and microclimate of forest canopies. In LOWMAN, MD. and NADKARNI, NM. (eds.). Forest Canopies (Physiological Ecology), Academic Press, San Diego, p. 73-106.

PICADO, C., 1913. Les broméliacées épiphytes. Considérées comme milieu biologique. Bulletin Science France Belgique, vol. 47 , no. 3, p. 215-360.

PITTENDRIGH, CS., 1948. The bromeliad-Anopheles-malaria complex in Trinidad. I - The bromeliad flora. Evolution, vol. 2, no. 1, p. 58-89.

POOLE, RW., 1974. An introduction to quantitative ecology. McGraw-Hill Inc, New York, USA, 532p. 
ROSSI, MR., MENDEZ, VH. and MONGENAJERA, J., 1997. Distribution of Costa Rican epiphytic bromeliads and the Holdridge Life Zone System. Revista de Biologia Tropical, vol. 45 , no. 3, p. 1021-1031.

SCARANO, FB., de MATTOS, EA., FRANCO, AC., HERZOG, B., BALL, E., GRAMS, TEE., MANTOVANI, A., BARRETO, S., HAAG-KERWER, A. and LÜTTGE, U., 1999. Habitat segregation of $\mathrm{C}_{3}$ and CAM Nidularium (Bromeliaceae) in response to different light regimes in the understory of a swamp forest in southeastern Brazil. Flora, vol. 194, no. 2/3, p. 281-288.

SCHIMPER, AFW., 1903. Plant geography upon a physiological basis. Clarendon Press, Oxford, 839p.

SCHLESINGER, WH. and MARKS, PL., 1977. Mineral cycling and the niche of Spanish moss, Tillandsia usneoides L. American Journal of Botany, vol. 64, no. 9, p. 1254-1262.

SILVERTOWN, J., 1987. Introduction to plant population ecology. 2nd. Longman Scientific \& Technical, New York, 320p.

SMITH, JAC., GRIFFITHS, H. and LÜTTGE, U., 1986. Comparative ecophysiology of $\mathrm{CAM}$ and $\mathrm{C}_{3}$ bromeliads. I.
The ecology of the Bromeliaceae in Trindad. Plant, Cell and Environment, vol. 9, no. 5, p. 159-176.

STUEFER, JF., DURING, HF. and DE KROON, H., 1994. High benefits of clonal integration in two stoloniferous species, in response to heterogeneous light environments. Journal of Ecology, vol. 82, no. 3, p. 511-518.

SUDGEN, AM. and ROBINS, RJ., 1979. Aspects of the ecology of vascular epiphytes in Columbian cloud forest. I. The distribution of epiphytic flora. Biotropica, vol. 11, no. 3, p. 173-188.

YODA, K., 1974. Three-dimensional distribution of light incidence in a tropical rain forest of West Malaysia. Japanese. Journal of Ecology, vol. 24, no. 2, p. 247-254.

ZAR, JH., 1999. Biostatistical analysis. $4^{\text {th }}$. Ed. Prentice-Hall, New Jersey, 663p.

ZOTZ, G., 1997. Substrate use of three epiphytic bromeliads. Ecography, vol. 20, no. 3, p. 264-270. 